\title{
Prevalence of Brucellosis in Cattle under Different Management Systems in Mbale District, Eastern Region of Uganda
}

\author{
Nasiru Mohammed $1^{*}$, Yusuf Muhammad Sanyinna ${ }^{2}$ and Ridwan Nuhu Ahmed 2 \\ ${ }^{1}$ Department of Environmental Science, Faculty of Science, Islamic University in Uganda. \\ 2 Department of Animal and Environmental Biology, Faculty of Life Sciences, Kebbi State University of Science and \\ Technology, Aliero - Nigeria.
}

International Journal of Biological and Pharmaceutical Sciences Archive, 2021, 02(02), 031-042

Publication history: Received on 19 October 2021; revised on 15 November 2021; accepted on 17 November 2021

Article DOI: https://doi.org/10.53771/ijbpsa.2021.2.2.0097

\begin{abstract}
The research study was conducted on prevalence of Brucellosis in cattle under different management systems in Mbale District, Eastern Region of Uganda. The research design adopted was a purposive sampling. 48 respondents from different farms were selected using a random sampling to allow equal representation of the farms. The data were collected using both blood samples and questionnaires. A total of 78 serum samples collected from different cattle were serologically assessed using Rose Bengal Plate Test (RBPT) and Serum Agglutination Test (SAT). The high seroprevalence of $37.5 \%$ was recorded in female cows followed by male bulls (20.0\%) and female calves (20.0\%). Bull calves and heifers showed negative result with RBPT and SAT $(0.0 \%)$. A total of $24(30.7 \%)$ and $22(28.2 \%)$ were recorded for RBPT and SAT respectively. However, although there was higher prevalence of Brucellosis in communal grazing than the rest of other grazing systems, there was no statistical significant difference between Brucellosis and grazing systems ( $p>0.05)$. Similarly, considering the type of breeding methods of fertilization, there was a statistically significant relationship between the type of breeding (artificial and natural insemination) methods and management system practiced $(\mathrm{p}<0.05)$. The study concluded that contamination of common grazing environment was due to aborted foetuses which is accompanied by shedding of large number of Brucella species and that there was lack of knowledge on the causative agents, as well as mode of transmission. The researchers recommend that cattle grazing systems that limit mixing of herds should be encouraged to reduce the contamination of common grazing environment.
\end{abstract}

Keywords: Prevalence; Brucellosis; Cattle; Management Systems; Mbale District.

\section{Introduction}

Brucellosis is a major zoonotic disease of public health importance in domestic animals, wild animals and humans [1]. It is one of the neglected zoonotic diseases in the world given little attention and often persists in the poorest and most vulnerable populations [2].

With the continuous and inevitable interaction of mankind and animals, the existence of Brucellosis provides a genuine hazard to both human and livestock health, mainly in urban and peri-urban areas where humans and animals live closely together.

The disease is caused by bacteria of the genus Brucella. The bacteria are non-motile, non-spore-forming, rod-shaped to coccoid and encapsulated in cells. They are facultative intracellular pathogens, hence more difficult to treat with antibiotics with preference for reproductive organs and mononuclear phagocytes, which they can multiply within [3].

\footnotetext{
* Corresponding author: Nasiru Mohammed

Department of Environmental Science, Faculty of Science, Islamic University in Uganda. 
Despite their parasitic ability, the bacteria can survive for some time in the environment: nearly a year in animal dung, more than 50 days on a wall during winter but less than a day during summer. Lysol or formalin or similar disinfectants kill Brucella quickly [4], and the bacteria die off when acidity drops below $\mathrm{p}^{\mathrm{H}} 3.5-4.0$. Pasteurization of milk products or proper meat preparation will have the same effect [5].

There are six (6) recognized species (and multitude biotypes) of the bacteria, which show strong host preference, although five of these six species can cross infect other animal hosts. Four of these six species can cause disease in humans: B. melitensis is the most pathogenic one, followed by B. suis, B. abortus and B. canis. Brucella ovis and B. neotomae are of lesser significance concerning human disease. It is probable that strains associated with marine animals i.e. other Brucella species dissimilar from the six mentioned, can infect humans [3]. The agent mainly responsible for Brucellosis in small ruminants is B. melitensis and it is also the primary cause of human Brucellosis [6].

Brucellosis is of great importance. Recent estimates of losses in meat and milk production as a result of Brucellosis are $\$ 800$ million annually in the USA [7]. Brucellosis infection in ruminants is endemic in Nigeria resulting in huge economic losses due to decreased calving percentage and delayed calving, culling for infertility, cost of treatment, decreased milk production, abortions, stillbirths, birth of weak calves and loss of man-hours in infected people [8].

The threat of bovine Brucellosis in Uganda is expected to increase much more since livestock is steadily increasing as evidenced by the livestock census of 2008 that showed an increment from 8.4 million in 2006 to 11.4 million in 2009 [9].

The disease occurs worldwide and it has been misdiagnosed as Malaria in human cases in Africa which causes a serious threat to public health. The major source of infection in people is undoubtedly domestic animals and therefore disease control in these animals is the most important measure to reduce human cases.

Meanwhile, Brucella infections in humans can cause an allergic reaction, characterized by a $1-2$ month incubation period followed by prolonged fever, night sweats, body aches, arthralgia and weakness [10]. According to Krause and Hendrick [11], Brucellosis in humans results in febrile illness, frequent chills, headaches and general weakness.

Humans get infected through consumption of raw milk, via skin abrasions or mucous membranes and inhalation. In cattle, it is usually spread by the vaginal discharge of an infected cow or an aborted foetus. Infected breeding bulls can transmit the disease to cows at the same time of service by infected semen.

Several factors such as livestock production systems, herd size, limited vaccine converge and availability, intervention with wild life, ecological and socio-economic factors are important in the epidemiology of the bovine Brucellosis [12]. Grazing systems have been reported as important factors in the epidemiology of bovine Brucellosis [13]. Cattle grazing system in Uganda differ widely, with the majority being communal (non-paddocked farms).

Cattle are natural grazers. They possess remarkable ability to digest plant carbohydrates that are generally indigestible to most other mammals. It is natural then to assume that grazing is the best way to supply nutrient dense diet to growing cattle.

Grazing system is a broad umbrella term and is defined as any integrated combination of animal, plant and other environmental components and the grazing method by which the system is managed to meet specific results or goals. A grazing method is a defined procedure or technique of grazing management designed to achieve a specific objective.

Communal grazing system entails grazing animals in designated grazing areas during the growing season and kraaling them at night. In this regard, animals are allowed free access to crop residues and stubbed after harvesting. In the lower rainfall areas where human and animal populations are sparse, cattle are sometimes neither herded nor kraaled at night [14]. They are allowed to graze freely away from homelands.

Zero grazing is a long established system of grazing control. The practice is becoming increasingly popular as a result of intensification of grassland management and the improvement of machinery for harvesting fresh herbage [15]. The system is believed to achieve a reduction in herbage wastage caused by selective grazing and by trampling and fouling. The system involves yarding (confining) the herds all year round and cutting the grass during the growing season for direct feeding of the animals. 
Pasture lands in the narrow sense are enclosed tracts of farmlands, grazed by domesticated livestock such as horses, cattle, sheep or swine. The vegetation of tended pasture forage consists mainly of grasses with an interspersion of legumes and other foods. Examples of pasture habitats are grassland, heathland, rangeland, rough pasture etc.

Tethering is a form of management system whereby single or a number of animals are tied to a length of rope and left to graze within the area the length of the rope allows. After some time, the animal can be moved to another area and tethered again for a period of about 4 to 8 hours per day.

Tethering may have negative impact upon the vegetation cover. Halving the tethering period of goats from eight to four hours per day increased the proportion of time spent grazing and saved a grazing on one patch. For example, prolonged grazing on one patch may lead to pasture loss that could result in increased soil erosion [16].

As Brucellosis is a disease with public health significance, and there is scarcity of information existing in Uganda, this study was aimed at determining the prevalence, risk factors as well as level of awareness of Bruc ellosis in cattle under different management systems in Mbale District, Eastern Region of Uganda.

\section{Material and Methods}

\subsection{Study Area}

\subsubsection{Location}

Mbale district is located in the Eastern region of Uganda. It lies between longitude $35^{\circ} \mathrm{E}$ and latitude $45^{\circ} \mathrm{N}$ with land area of 534.4 sq. $\mathrm{km}$ and population density of 620 people per square kilometre.

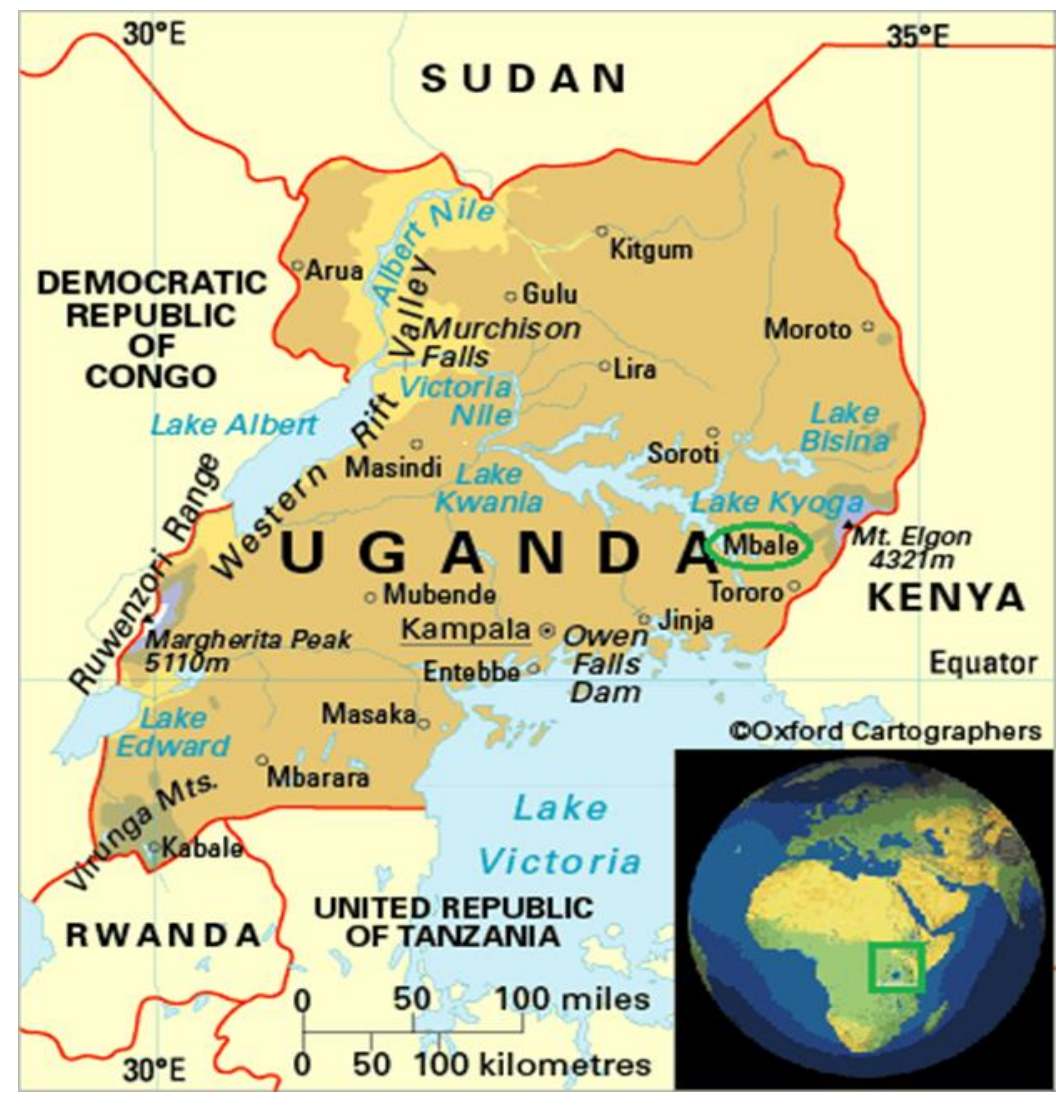

Figure 1 A Map of Uganda Showing Some Neighbouring Countries with Mbale District Circled Green (Source: Oxford Cartographers) 


\subsubsection{Climate}

Mbale experiences a sub-tropical type of climate with more distinctive rainy and dry season between April to June and September to November. It receives a mean of $1000 \mathrm{~m}$ [17]. The maximum temperatures are 15 and $23^{\circ} \mathrm{C}$ respectively [18].

\subsubsection{Vegetation}

It is mainly Savannah ranging from tropical grassland plains with forests and alpines vegetation toward the mountain summit.

\subsubsection{Study Population}

Mbale has an estimated population of 441,300 living in 1901 households [9]. With the majority of farmers (31\%) having a small number of cattle and goats as an asset, and a very limited large-scale dairy farms in the District. Predominant breeds in the area are indigenous and exotic breeds.

\subsubsection{Study Design}

Purposive sampling was used to select 48 herds of cattle out of which 5 are large-scale farms within Mbale and the remaining are household cattle keepers with an average herd size of $\geq$ four (4) cattle.

A pilot study that lasted for 1 week was conducted at the beginning of the study.

Field work for this study was carried out between April and June, 2015. Semi structured questionnaires and blood samples were collected.

\subsection{Sample Size Estimation}

The sample size was determined using the formula of Mogan (1970) as cited in Nachuha et al. [19] given below;

$$
\mathrm{n}=\frac{N}{1+N(e)^{2}}
$$

Where; $\mathrm{n}$ is the sample size, $\mathrm{N}$ is the population size and $\mathrm{e}=5 \%(0.05)$ is the level of significance.

\subsection{Ethical Consideration}

Prior to data collection with the farms, the research was introduced to the District Veterinary Office through introductory letter from the Dean Faculty of Science, Islamic University in Uganda.

The study was then introduced to the farm care-takers with the aid of research assistants.

\subsection{Questionnaire}

Verbal consent was obtained from the respondents and the objective of the survey explained to them before the start of the interview. The questionnaire focused on demographic characteristics of the farm caretakers/owners, animal feeding, housing practices, knowledge about Brucellosis, habit of animal product consumption, aborted foetal disposal practices etc.

\subsection{Sample Techniques and Procedures}

Five (5) millilitre of uncoagulated blood was collected aseptically from the jugular vein (venipuncture). The samples were transported in vacuum containers to the laboratory and allowed to clot. Serum formed was then stored at $-20^{\circ} \mathrm{C}$ until required for use. A total of 78 serum samples were collected from all the 48 cattle farms of the District. The Rose Bengal Plate Test (RBPT) and Serum Agglutination Test (SAT) were employed. RBPT depends on early detection of Brucella specific antigens by using antigen stained with Rose Bengal and buffered to a low $\mathrm{p}^{\mathrm{H}}$ usually $3.65 \pm 0.0$. The test was conducted as described in the manual of standards for diagnostic tests and vaccines [20,21].

Serum samples and RBPT antigens were brought to room temperature then $30 \mu \mathrm{l}$ of serum were transferred to a clean, dry and grease-free glass slide by micro-pipette. The antigen bottle was shaken to ensure homogenous suspension; then $30 \mu \mathrm{l}$ of the antigen was added. The antigen and serum were mixed thoroughly with a spreader and then the slide was 
agitated gently for 4 minutes. The result was noted immediately after 4 minutes. Any visible described reaction after 4 minutes was considered to be true.

SAT was performed in micro-plates according to OIE [20]. Surplus showing more than $30 \mu \mathrm{l} / \mathrm{millilitre}$ was considered positive.

\subsection{Validity of the Instrument}

Validity refers to the extent to which an instrument tests what it is intended to test and what is officially acceptable.

To ensure validity of the instrument, the questionnaire was developed under close guidance by the supervisor. After the question items are designed, pilot testing of copies of the questionnaire were administered to respondents from the sample but who were not part of the respondents for the study. This helped to assess the language clarity, ability to tap information from respondents, acceptability in terms of length and ethical consideration for respondents. The instrument was presented to experts in the field of study to establish face and content validity.

The instrument was designed by matching the questions with the objectives stated for the study. The initial draft was reviewed after which the researchers showed it to two other research students. Next, the researchers showed it to the supervisors who gave useful advice for improving the content, wording and layout of the instrument.

The instrument was then subjected to CVI using the following formula:

$$
\mathrm{CVI}=\frac{\text { Number of items rated as relevant }}{\text { Total number of items in the questionnaire. }}
$$

The result of CVI is 0.87 . The value is above the 0.7 standard value for validity. Hence, the instrument is considered valid for the study.

\subsection{Reliability of the Instrument}

Reliability is the ability of the research instrument to yield consistent result. It is the degree of consistency or dependability of the instruments in relation to what it is meant to test.

A pilot study using the test-retest method was carried out. A selected sample was given the questionnaires to answer and the responses were quantified to form percentages. After a period of two weeks, the same questionnaires were given to the same group of subjects and responses recorded. The researcher employed the use of test-retest reliability coefficient in order to establish reliability for the study. The calculated Cronbach's coefficient alpha value of reliability was 0.718 .

\subsection{Methods of Data Analysis}

The analysis was done using descriptive statistics, frequency and cross tabulation to determine the relationship between the prevalence of Brucellosis and management systems, and chi-square to test if there is significant difference.

\section{Results and Discussion}

Below is the presentation of the analysis of the data collected, interpreted and the findings of the study. The data have been presented in chronological order with the study objectives.

\subsection{Prevalence of Brucellosis}

A total of 78 serum samples were collected from 48 different farms in Mbale District (Table 1). The high seroprevalence of $37.5 \%$ was recorded in female cows. This study however contrasted with a study by Magona et al. [22] that reported $34.0 \%$ prevalence rate in Uganda.

In order to determine the prevalence of Brucellosis in cattle under different management systems in Mbale District, the data obtained were analyzed using chi-square statistical tools. Tables 2 and 3 below present the result generated respectively. 
Table 1 The Prevalence of Brucellosis in Cattle Herds in Mbale District

\begin{tabular}{|l|c|c|c|}
\hline \multicolumn{1}{|c|}{ CATTLE } & T/NO & RBPT & SAT \\
\hline Cows & 56 & $21(37.5 \%)$ & $20(35.7 \%)$ \\
\hline Bulls & 10 & $2(20.0 \%)$ & $2(20.0 \%)$ \\
\hline Bull calves & 4 & $0(0.0 \%)$ & $0(0.0 \%)$ \\
\hline Heifers & 3 & $0(0.0 \%)$ & $0(0.0 \%)$ \\
\hline Female calves & 5 & $1(20.0 \%)$ & $0(0.0 \%)$ \\
\hline Total & 78 & $24(30.7 \%)$ & $22(28.2 \%)$ \\
\hline
\end{tabular}

Key: $\mathrm{T} / \mathrm{NO}=$ Total Number; RBPT = Rose Bengal Plate Test; SAT = Serum Agglutination Test; $\%=$ percent.

Table 2 Chi-Square Test for the Prevalence of Brucellosis in Different Cattle Management Systems in Mbale District

\begin{tabular}{|c|c|c|c|c|c|c|c|c|c|}
\hline \multicolumn{9}{|c|}{ Cross-Tabulation } & \multicolumn{7}{|c|}{ Chi-Square Tests } \\
\hline \multicolumn{2}{|c|}{$\begin{array}{l}\text { What type of cattle management system do you practice? } \\
\text { Grazing }\end{array}$} & Tethering & Pasture & $\begin{array}{l}\text { Zero } \\
\text { Grazing }\end{array}$ & Total & $\boldsymbol{x}^{\mathbf{2}}$ & $\begin{array}{l}\text { Linear-by- } \\
\text { Linear } \\
\text { Association }\end{array}$ & Df & $\begin{array}{l}\text { Asymp. Sig. } \\
\text { (2-sided) }\end{array}$ \\
\hline SAT & 17 & 3 & 0 & 2 & 22 & - & 2.644 & 1 & .104 \\
\hline RBPT & 14 & 8 & 0 & 2 & 24 & - & 3.637 & 1 & .057 \\
\hline
\end{tabular}

Key: RBPT = Rose Bengal Plate Test; SAT = Serum Agglutination Test; $x^{2}=$ Chi-Square; Df = Significant Difference; Asymp.Sig. = Asymptotic Significance; - = absent.

Results presented in Table 2 above showed the Pearson Chi-square $(p>0.05)$.

However, although there was higher prevalence of Brucellosis in communal grazing than the rest of the other grazing systems, there was no statistical significant relationship between Brucellosis and grazing systems.

Table 3 Chi-Square Test for the Kind of Breeding Methods on the Farm in Mbale District

\begin{tabular}{|c|c|c|c|c|c|c|c|c|c|}
\hline \multicolumn{5}{|c|}{ Cross-Tabulation } & \multicolumn{5}{|c|}{ Chi-Square Tests } \\
\hline \multicolumn{10}{|c|}{ What type of cattle management system do you practice? } \\
\hline & $\begin{array}{l}\text { Communal } \\
\text { Grazing }\end{array}$ & Tethering & Pasture & \begin{tabular}{|l|} 
Zero \\
Grazing
\end{tabular} & Total & $\begin{array}{l}x^{2} \\
\text { Value }\end{array}$ & $\begin{array}{l}\text { Linear-by- } \\
\text { Linear } \\
\text { Association }\end{array}$ & Df & $\begin{array}{l}\text { Asymp.Sig. } \\
\text { (2-sided) }\end{array}$ \\
\hline \multicolumn{10}{|c|}{ What kind of breeding methods do you use on this farm? } \\
\hline $\begin{array}{l}\text { Artificial } \\
\text { Insemination }\end{array}$ & 0 & 0 & 2 & 12 & 14 & $96.000^{\mathrm{a}}$ & - & 6 & .000 \\
\hline $\begin{array}{l}\text { Natural } \\
\text { Methods }\end{array}$ & 0 & 15 & 0 & 0 & 15 & - & - & - & - \\
\hline $\begin{array}{ll}\text { Artificial and } \\
\text { Natural } \\
\text { Methods }\end{array}$ & 19 & 0 & 0 & 0 & 19 & - & 44.515 & 1 & .000 \\
\hline Total & 19 & 15 & 2 & 12 & 48 & & 48 & & \\
\hline
\end{tabular}

Key: $x^{2}$ = Chi-Square; Df = Significant Difference; Asymp.Sig. = Asymptotic Significance; - = absent.

Results presented in Table 3 above revealed that the Pearson Chi-square $(\mathrm{p}<0.05)$ for the prevalence of Brucellosis on cattle grazing system indicating a statistically significant relationship between type of breeding method and management system practiced. Hence, it means that the type of breeding method for fertilizing the animals contributed to the prevalence of Brucellosis in cattle under different management systems in Mbale District. 
The higher prevalence recorded in the female than in the male may result from the fact that the foci of infection remain in females which spread the infection from one animal to another as observed by Ogundipe et al. [23]. Similarly, it appears that female cows are generally more susceptible to Brucellosis than the males because of D-erythritol, an alcohol normally found in higher volume in foetal tissues in pregnant female cows than in seminal vesicles and testes of the males and is known to stimulate the growth of virulent strains of Brucellosis.

\subsection{Risk Factors of Brucellosis}

Based on the respondents' assessment (Table 4), it was evident that majority of the respondents 36(46.2\%) have agreed that their animals gave birth in the same fence where they graze and even some do assist their animals when giving birth. This finding is in agreement with the view of Schelling et al. in Chad [24].

Based on the livestock associated risk factors, Kungu et al. stated that cattle grazing system has been an important factor in the epidemiology of Brucellosis [13].

Table 4 The Risk Factors Associated with Brucellosis in Mbale District

\begin{tabular}{|c|c|c|}
\hline Attribute & Frequency & Percentage \\
\hline \multicolumn{3}{|c|}{ Have you brought any animal onto your farm during the past three (3) years? } \\
\hline Yes & 29 & $37.2 \%$ \\
\hline No & 19 & $24.4 \%$ \\
\hline \multicolumn{3}{|c|}{ If you brought any animal onto your farm, which sex were they? } \\
\hline Male & 0 & $0.0 \%$ \\
\hline Female & 48 & $61.5 \%$ \\
\hline \multicolumn{3}{|c|}{ Do you hire other people's bulls/bucks for breeding your animals? } \\
\hline Yes & 19 & $24.4 \%$ \\
\hline No & 14 & $17.9 \%$ \\
\hline \multicolumn{3}{|l|}{ Where do your animals give birth? } \\
\hline In separate maternity pens. & 12 & $15.4 \%$ \\
\hline On pasture. & 36 & $46.2 \%$ \\
\hline Left to dry and collected later. & 34 & $43.6 \%$ \\
\hline Use of biogas and carried to field. & 14 & $17.9 \%$ \\
\hline \multicolumn{3}{|l|}{ How do you feed your animals? } \\
\hline Mainly concentrated feeding and tethering grazing. & 30 & $38.5 \%$ \\
\hline Pasture plus grass. & 2 & $2.6 \%$ \\
\hline Pasture plus supplements all year. & 12 & $15.4 \%$ \\
\hline Pasture plus supplements occasionally. & 19 & $24.4 \%$ \\
\hline Mainly concentrated feeding. & 15 & $19.2 \%$ \\
\hline
\end{tabular}

Results in Table 4 revealed that majority of the respondents 36(46.2\%) have agreed that their animals gave birth in the same grazing fences, while some of the farmers $12(15.4 \%)$ had separate maternity fences.

Cooper observed that: an aborted storm in a herd of livestock is among the common features of Brucellosis in livestock [25]. During abortion, large numbers of Brucella are released which may contaminate the grazing environments thereby causing infection to other animals in the herds in contact with livestock during parturition. This is a strong risk factor for Brucellosis as observed in Chad and Saudi Arabia by Schelling et al. and Cooper respectively [24, 25]. 
The contamination of the grazing environment was attributed to improper hygienic management practices by majority of the herdsmen in disposing aborted foetuses, placenta and vaginal discharges during parturition. These contain virulent $B$. abortus which contaminate the grazing environment as well as the pasture and water, and serve as reservoirs of infection to other cattle in the same grazing fences as observed by Corbel [26].

According to Acha-Pedro and Szyfres, the most common route of transmission in cattle is through direct contact with an aborting cow and the aborted foetus or by direct contact with contaminated fomites [27]. Ingestions of contaminated pasture, feed, fodder and water may also play a secondary role. Although Brucellosis has been almost eradicated from most of the developed countries, it is still a major public and animal health problem in many developing countries, where livestock are a major source of food and income. The incidence of human Brucellosis is correlated with the level of incidence in domestic animals. Human cases occur after ingesting raw milk and milk products and coming into close contact with infected animals [28].

Other risk factors that influenced the prevalence of Brucellosis include management system as observed by Manthei and Carter [29].

Junaidu et al. also observed that: the herding of different species together and use of common grazing and water source is also a risk factor in Brucellosis infection [30].

According to Corbel et al., in livestock, there is a greater susceptibility to Brucellosis in sexually matured animals; although it is possible for young animals to be latently infected and these animals may eventually become a source of infection when matured [3].

\subsection{Level of Awareness of Brucellosis}

Table 5 Level of Awareness of Brucellosis in Different Management Systems in Mbale District

\begin{tabular}{|l|c|c|}
\hline \multicolumn{1}{|c|}{ Attribute } & Frequency & Percentage \\
\hline Whether any cow aborted. \\
\hline Yes & 15 & $19.2 \%$ \\
\hline No & 21 & $26.9 \%$ \\
\hline Which part of animal pregnancy aborted? \\
\hline First three months & 12 & $15.4 \%$ \\
\hline Middle of pregnancy & 21 & $26.9 \%$ \\
\hline Do you have infertile animals? \\
\hline Yes & 14 & $17.9 \%$ \\
\hline No & 34 & $43.6 \%$ \\
\hline Have you heard of Brucellosis? \\
\hline Yes & 29 & $37.2 \%$ \\
\hline No & 19 & $24.4 \%$ \\
\hline Have you ever conducted a test for Brucellosis? \\
\hline Yes & 0 & $0.0 \%$ \\
\hline No & 21 & $26.9 \%$ \\
\hline
\end{tabular}

Results in Table 5 above revealed that majority of the respondents $29(37.2 \%)$ were aware of the disease called Brucellosis, but showed ignorance about the disease's signs and symptoms.

A majority of the respondents $21(26.9 \%)$ stated that they had somewhat knowledge of the disease. However, their knowledge was rather imperfect when it comes to the disease's signs and symptoms. While 15(19.2\%) mentioned 
abortion in animals (this showed that, minority of the respondents added other random symptoms such as lumpy skin diseases, udder infections, simple tick fever and pains from injury or slippery as well to their answers).

However, this study has confirmed the lack of knowledge of the farmers on the causative agent, transmission mode and preventive measures for Brucellosis in the study area. Ignorance about the disease was more prevalent among the cattle herd personnel who had acquired low formal education and yet they form main workforce in the milk industry.

Many countries currently appreciate the need to assess the safety and quality of foods, because of the global recognition of the role of foods in spreading diseases and food poisoning [31].

\section{Conclusion}

The study concluded that, the detection of Brucella antibodies in the sera of cattle in this study area is significant and suggested that, apparently healthy animals are potential sources of infection of Brucellosis and may pose a risk to public health and shows that infected cattle are potential hazards to consumers of milk and milk products in the region.

The study further concluded that, contamination of common grazing environment was due to aborted foetuses which is accompanied by shedding of large number of Brucella species.

It was also concluded that, there is lack of knowledge on the causative agents, mode of transmission, prevention and control measures against Brucellosis in the study area. The occupational workers wear no protective gear apart from gum boots.

\section{Recommendations}

Based on the conclusions of this study on the prevalence of Brucellosis in cattle under different management systems in Mbale District, Eastern Region of Uganda, the following recommendations were made out of the study findings:

- There should be a development of a comprehensive strategy to include well laid monitoring of the infected livestock. This recommendation was based on the secondary factors that could lead to the spread of Brucellosis.

- Cattle grazing systems that limit mixing of herds should be encouraged to reduce the contamination of the common grazing environment.

- More sensitization programs should be carried out among the various livestock handlers, especially on the mode of transmission, etiology and coverage of Brucellosis to the general public and its public health implications. There should also be better strategies to enable farmers get advice and support from veterinary officers.

- Close surveillance should be carried out regularly in the District for the control of Brucellosis in domestic animals as the prevalence is likely to increase drastically in the near future.

\section{Areas for further study}

- Further studies should be done on other infectious diseases in animals. This study focused mainly on Brucellosis and hence the results obtained from these findings may not be conclusive enough to be generalized to other animal disease.

- There is need for a study on the milk and milk products processing methods to come up with standard operation procedures to safeguard the public.

\section{Compliance with ethical standards}

\section{Acknowledgements}

We sincerely acknowledge the highly spirited concern, dedication and expertise of the supervisor of this research work (Dr. Adiukwu Roseline). May Almighty God reward her abundantly.

We equally wish to thank the questionnaire respondents without whom this study could not be completed. 
Our best wishes go to the management and educational tycoons, teaching and non-teaching staff of Islamic University in Uganda (IUIU).

\section{Disclosure of conflict of interest}

The authors declared that there is no conflict of interest in this research work.

\section{Statement of ethical approval}

Prior to data collection with the farms, the research was introduced to the District Veterinary Office through introductory letter from the Dean Faculty of Science, Islamic University in Uganda. The study was then introduced to the farm caretakers with the aid of research assistants. Verbal consent was obtained from the respondents and the objective of the survey explained to them before the start of the interview. No animal was harmed during the conduct of this research.

\section{Statement of informed consent}

Informed consent was obtained from all individual participants included in the study.

\section{References}

[1] OIE. Bovine Brucellosis. In: Manual of Diagnostic Tests and Vaccines for Terrestrial Animals (Mammals, Birds and Bees). 2008; 624-659.

[2] FAO. Food and Agriculture Organization of the United Nations: The State of Food and Agriculture. 2009.

[3] Corbel MJ, et al. Brucellosis in Humans and Animals. The World Health Organization in Collaboration with Food and Agriculture Organization of the United Nations and the World Organization for Animal Health. Geneva: WHO Press. 2006.

[4] Epiwebb. Brucellosis. 2012.

[5] FAO. Food and Agriculture Organization of the United Nations: The State of Food and Agriculture. ISSN 00814539, Rome. 2010.

[6] Blasco JM, Molina-Flores B. Control and Eradication of Brucella melitensis Infection in Sheep and Goats. Vet Clin Food Anim. 2011; 27: 95-104.

[7] Richey EJ, Harrell DC. Brucella abortus Disease (Brucellosis) in Beef Cattle, UF/IFAS. 1997.

[8] Mai HM, Irons PC, Kabir J, Thompson PN. A Large Seroprevalence Survey of Brucellosis in Cattle Herds under Diverse Production Systems in Northern Nigeria. Biomed Central Veterinary Research. 2012.

[9] UBOS/MAAIF. Summary Report of the National Livestock Census, 2008. Uganda Bureau of Statistics/Ministry of Agriculture, Animal Industry and Fisheries. Kampala - Uganda. 2009.

[10] Punda-Polic B, Cuetnic Z. Human Brucellosis in Crotia. Lancet Infect Dis. 2006; 6(9): 540-541.

[11] Krause DO, Hendrick S. Zoonotic Pathogens in the Food Chain. CAB International, Nosworthy Way, Wallingford, Oxfordshire OX10 8DE, UK, England. Biology. 2010.

[12] Kabagambe, E. K., Elzer, P. H., et al. Risk Factors for Brucella Seropositivity in Goat Herds in Eastern and Western Uganda. 2001.

[13] Kungu JM, et al. Sero-prevalence and Risk Factors for Brucellosis in Cattle in Gulu and Amuru Districts, Northern Uganda. African Journal of Animal Health and Production in Africa. 2010; 204-229.

[14] Cousins B. Evaluation of Pilot Cattle Grazing Schemes. Report by EEC and Agritex, Harare. 1988.

[15] Adewumi 00, Aina ABJ, Oduguwa OB. APH 509: Beef Animal Production (Lecture Notes). Department of Animal Production and Health, Federal University of Agriculture, Abeokuta, Nigeria. 2003.

[16] Minde I, Mtinga LA. Tether Grazing Goats in Tanzania. Sokoine University of Agriculture, Morogoro, Tanzania. Veterinary Sciences and Comparative Medicine. Academic Press, London. 1996.

[17] NEMA. State of the Environment Report - 2010 - Uganda. National Environment Management Authority Uganda. 2010. 
[18] Mugagga F, Kakembo V, Buyinza M. A Characterization of the Physical Properties of Soil and the Implications for Landslide Occurrence on the Slopes of Mount Elgon, Eastern Uganda. Natural Hazards. 2011.

[19] Nachuha S, Ejotre I, Mwima PM. The Role of Ciconiiformes in Controlling Pests in Rice Paddies of Kibimba, Eastern Uganda. Rehabilitation Medicine. 2014; 2(12): 797-806.

[20] OIE. Bovine Brucellosis. Manual of Diagnostic Tests and Vaccines for Terrestrial Animals. Office International des Epizootics, Paris. 2009.

[21] OIE. Bovine Brucellosis: Terrestrial Manual. Version adopted by the World Assembly of Delegates of the Office International des Epizooties in. May 2009; 1 - 35.

[22] OIE. Bovine Brucellosis. In: Manual of Diagnostic Tests and Vaccines for Terrestrial Animals. Paris, France. World Organisation for Animal Health Report. Series. 2011; 1 - 35.

[23] Magona JW, Walubengo J, Galiwango T, Etori A. Seroprevalence and Potential Risk of Bovine Brucellosis in Zero Grazing and Pastoral Dairy Systems in Uganda. Trop. Anim. Health Prod. 2009; 41: 1765-1771.

[24] Ogundipe GAT, Oyeyemi MO, Ijagbone IF. Sero-prevalence of Brucella abortus Agglutinins in Slaughtered Cattle in Ibadan. Trop. Veterinarian. 1994; 12: 158-161.

[25] Schelling E, Diguimbaye C, Daoud S, Nicolet J, Boerlin P, Tanner M, Zinsstag J. Brucellosis and Q-fever Seroprevalence in Nomadic Pastoralists and their Livestock in Chad. Preventive Veterinary Medicine. 2003; 61(4): 279-293.

[26] Cooper CW. Risk Factors in Transmission of Brucellosis from Animals to Humans in Saudi Arabia. Trans R Soc Trop Med Hyg. 1992; 86(2): 206-209.

[27] Corbel, M. J., Thomas, E. L. et al. Use of Phage for the Identification of Brucella canis and Brucella ovis Cultures. Res Vet Sci. 1985; 38(1): 35-40.

[28] Acha-Pedro N, Szyfres B. Zoonoses and Communicable Diseases Common to Man and Animals: Bacteriosis and Mycosis. Scientific and Technical Publication No. 580. Pan American Health Organization, American Sanitary Bureau, Regional Office of the World Health Organization, DC. 2001; 3(1): 40-62.

[29] FAO. Food and Agriculture Organisation of the United Nations. Guidelines for Coordinated Human and Animal Brucellosis Surveillance. FAO Anim. Prod. Hlth Pap. 2003; 156(45).

[30] Manthei CA, Carter RW. Persistence of B. abortus Infection in Cattle. American Journal of Veterinary Research. 1950; 173(39): 180.

[31] Junaidu AU, Obovegbulem SI, Salihu MD. Seroprevalence of Brucellosis in Prison Farm in Sokoto, Nigeria. Asian Journal of Epidemiology. 2008; 1(1): 24-28.

[32] Newell DG, Koopmans M, Verhoef L, Duizer E, Aidara-Kane A, Sprong H, Opsteegh M, Langelaar M, Threfall J, Scheutz F, van der Giessen J, Kruse H. Food-borne Diseases - the Challenges of 20 Years Ago Still persist While New Ones Continue to Emerge. International Journal of Food Microbiology. 2010; 145(2-30): 493.

\section{Authors' Short Biography}

Mr. Nasiru Mohammed had a B. Sc. (Hons.) Microbiology degree from Usmanu Danfodiyo
University, Sokoto, Nigeria, M. Sc. Environmental Science of Islamic University in Uganda and M. Sc.
Microbiology and Biotechnology, Department of Microbiology, Institute of Molecular Biology and
Biotechnology, The University of Lahore, Pakistan. He had worked with Infectious Diseases Hospital
and Public Health Laboratory, Amanawa, Sokoto and currently a Lecturer in Umaru Ali Shinkafi
Polytechnic, Sokoto, Nigeria. He has a lot of experiences in different fields.




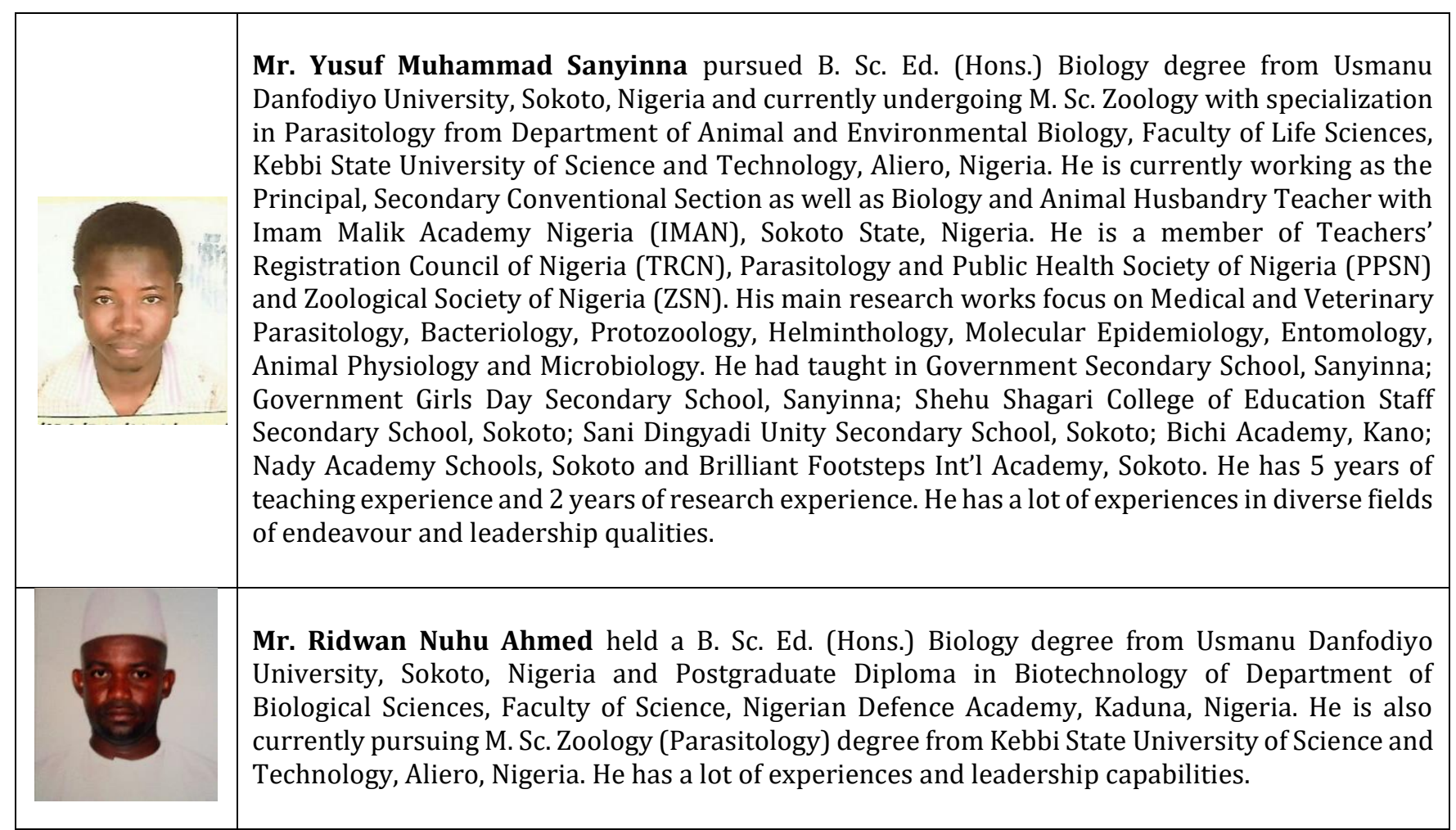

